\title{
Technical Economic and Environmental analysis of Chemical Looping versus oxyfuel combustion for NGCC power plant
}

\author{
Pietro Bartocci ${ }^{1,2}$, Alberto Abad ${ }^{1}$, Arturo Cabello ${ }^{1}$, Mauro Zampilli², Giulio Buia ${ }^{2}$, Angela \\ Serra $^{3}$, Simone Colantoni ${ }^{3}$, Andrea Taiana ${ }^{3}$, Gianni Bidini' ${ }^{2}$, Francesco Fantozzi ${ }^{2}$ \\ ${ }^{1}$ Instituto de Carboquímica (ICB-CSIC), Miguel Luesma Castán 4, 50018, Zaragoza, Spain \\ ${ }^{2}$ Department of Industrial Engineering, University of Perugia, Via G. Duranti 67, 06125 Perugia, Italy \\ ${ }^{3}$ Baker Hughes, Piazza Enrico Mattei, 50127 Firenze, Italy
}

\begin{abstract}
The Power Sector is undergoing a rapid technological change with respect to implementation of low carbon technologies. The IEA Energy Outlook 2017 shows that the investments in Renewables for the first time are equal to those on the fossil sources. It is likely that the conventional gas turbines and internal combustion engines will need to be integrated in systems employing biofuels and/or CCUS (Carbon Capture Usage and Storage). Also, the European Union is moving rapidly towards low carbon technologies (i.e. Energy Efficiency, Smart Grids, Renewables and CCUS), see the Energy Union Strategy. Currently $28 \%$ of the installed power capacity in Europe is based on natural gas plants. Gas-based power capacity has reached $418 \mathrm{GW}$ in 2016 and is likely to continue to grow in the future. To efficiently capture the carbon dioxide emissions generated by the combustion of natural gas in the combustion chamber a possible solution could be to adopt new combustion processes, like Chemical Looping Combustion. The combination of CLC and GTs can decrease the efficiency of a combined cycle power plant from $60 \%$ to about $40.34 \%$. These performances influence costs and environmental burdens and this is also the same for oxyfuel combustion, which is a competing technology to realize CCS. This paper, starting from literature mass and energy balances of a conventional combined cycle, a combined cycle coupled with chemical looping combustor and a combined cycle coupled with oxyfuel combustion, calculates the reduction of $\mathrm{CO} 2$ emissions which can be achieved during the whole life cycle of the power plant and then identifies the value of the carbon credit which is needed to have an interesting payback period for such kind of investment.
\end{abstract}

\section{Introduction}

The Power Sector is undergoing a rapid technological change with respect to implementation of low carbon technologies. The IEA Energy Outlook 2017 showed that the investments in Renewables for the first time are equal to those on the fossil sources [1]. For this reason, it is likely that the conventional gas turbines and internal combustion engines will need to be integrated in systems employing biofuels and/or CCUS (Carbon Capture 
Usage and Storage). Also the European Union is moving rapidly towards low carbon technologies (i.e. Energy Efficiency, Smart Grids, Renewables and CCUS), see the Energy Union Strategy [2].

Currently $28 \%$ of the installed power capacity in Europe is based on natural gas plants [3]. In 2018 the installed CC plants had a capacity of $132.6 \mathrm{GW}$ in the EU28 [1]. Power plants based on only gas turbines had a capacity of $15.9 \mathrm{GW}$ and power plants based on only steam turbines had a capacity of $129.7 \mathrm{GW}$ [1]. To efficiently capture the carbon dioxide emissions generated by the combustion of natural gas in the combustion chamber a possible solution could be to adopt new combustion processes, like Chemical Looping Combustion. Italy in particular has more than $57 \mathrm{NG}$ power stations and a total capacity of about $40 \mathrm{GW}$ [5] (which is in great part contained in the World Power Plants Database [6], which covers about $98 \%$ of the installed capacity). We see from [6] that $89 \%$ of the total NG power plants are represented by NGCC, $3 \%$ are represented by Integrated Gasification Combined Cycles (IGCC) and $8 \%$ are represented by gas turbines.

CLC it is a form of unmixed combustion which uses an oxygen carrier to transfer oxygen from air to fuel. Thus the combustion products, $\mathrm{CO}_{2}$ and $\mathrm{H}_{2} \mathrm{O}$, are obtained in a separate gas flow, see Figure 1, and $\mathrm{H} 2 \mathrm{O}$ is easily removed by condensation. In this way, the carbon dioxide (CO2) is kept separate from the nitrogen in the air, and no energy is needed to capture the $\mathrm{CO} 2$, because air and fuel are never mixed.

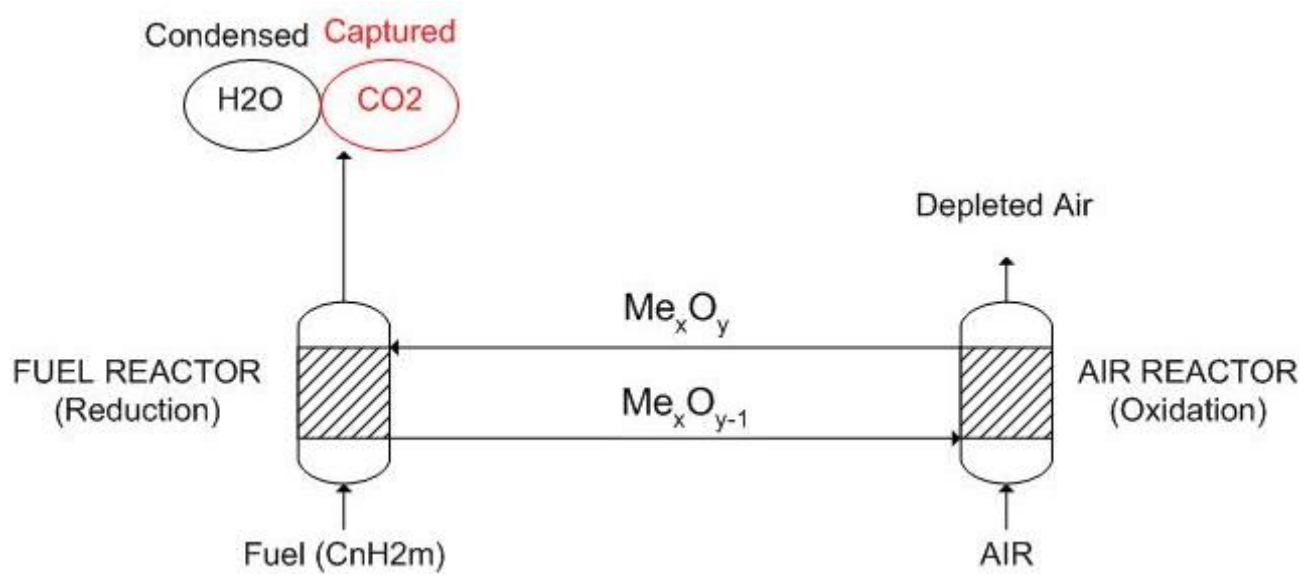

Fig. 1. Chemical Looping Combustion (CLC) technology

The combination of CLC and GTs can decrease the efficiency of a combined cycle power plant from $60 \%$ to about $40.34 \%$ [7]. This implies the need of more natural gas to be burned to maintain the same electricity production. Also investment costs are likely to increase for this kind of plants. We can consider that the combustion chamber accounts for $11 \%$ of the total investment in the turbine [8] and that the investment for a pressurized fluidized bed combustor can range between 2140 - $5700 \$ / \mathrm{kW}[9]$.

Based on these economic figures a complete financial analysis of the investment required for a conventional CC power plant and a CC with CLC power plant is performed. In the economic analysis a sensitivity analysis on the price of the carbon credit is performed to understand at what price the investment becomes interesting.

Besides this a complete analysis of the life cycle of the two power plants is performed to understand if the loss of efficiency of the plant using the chemical looping combustor affects the environmental performances. Then using the EnergyPlan software the large- 
scale impact of the proposed technology is evaluated relatively to the Italian Energy System.

\section{Materials and Methods}

\subsection{Chemical Looping Combustor: costs and impact}

Much research has been done on the optimization of the configuration of CLC burners when coupled with NGCC plants. For example, in the work of Khan [10] an interesting concept plant in which CLC is integrated with NGCC is proposed. The paper tries to reduce the energy penalty which is due to the fact that when integrated into a natural gas combined cycle (NGCC) plant, the CLC combustor works at a maximum achievable reactor temperature which is far below the firing temperature of state-of-the-art gas turbines. The proposed plant circumvents this limitation via an added combustor after the CLC reactors; in this way, a standard gas turbine can be deployed, and $\mathrm{CO}_{2}$ avoidance costs are reduced to $\$ 60.3 /$ ton, mainly due to a reduction in the energy penalty to only $1.4 \%$-points [10]. However, due to the natural gas combustor which is added after the CLC reactor, $\mathrm{CO}_{2}$ avoidance is only $52.4 \%$ [10]. Achieving high $\mathrm{CO}_{2}$ avoidance requires firing with clean hydrogen instead, increasing the $\mathrm{CO}_{2}$ avoidance cost to $\$ 96.3 /$ ton when a hydrogen cost of $\$ 15.5 / G J$ is assumed [10]. A simplified scheme of a NGGT with a coupled Chemical Looping Plant is shown in Figure 2. In figure 2 we see that the fuel reactor (where reduction happens) and the air reactor (where oxidation happens) are interconnected. The air used to oxidise the oxygen carrier is previously compressed and then after exiting the air reactor it expands in the gas turbine. In a simplistic way the process can be considered similar to an external combustion gas turbine where the heat exchanger between exhaust combustion gases and air is missing.

\begin{tabular}{l} 
Legend \\
1: Compressor \\
2: Turbine \\
3: Combustion chamber \\
\hline
\end{tabular}

\section{Performance comparison}

TIT-CLC: $900-978^{\circ} \mathrm{C}$

TIT-CC: $1300^{\circ} \mathrm{C}$

B-CLC: 5 bar

$\beta$-CC: 23 bar

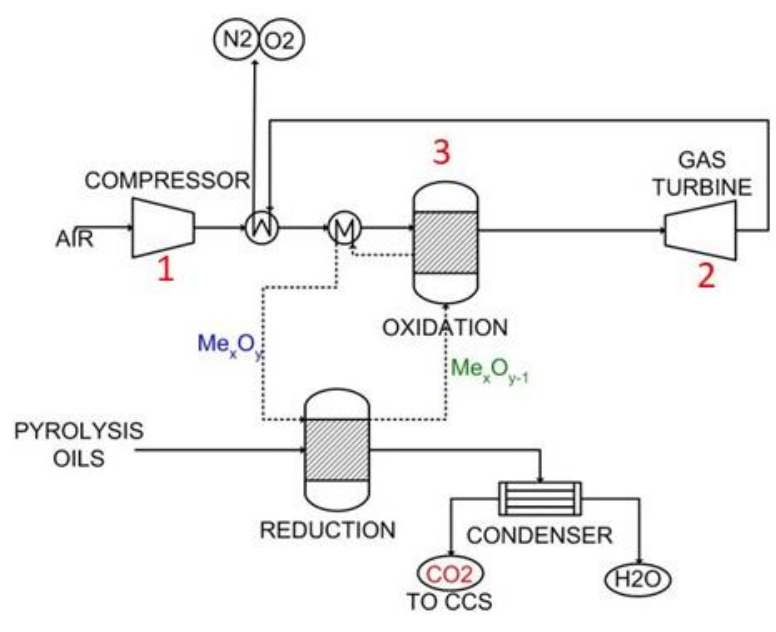

Fig. 2. Coupled NGGT and CLC combustor

Such a plant has the following characteristics:

- costs are about: $0.1 \mathrm{M} € / \mathrm{MW}$; costs are mainly evaluated based on pressurized fluidized bed costs; 
- the plant duration is estimated to be 30 years;

Fan et al. 2018 [11] have performed an interesting study on the Life Cycle Assessment (LCA) of CLC plants coupled to CC fed with natural gas. They have studied the influence on the final impact of 4 technical factors: the type of oxygen carrier, its life, the environmental impact caused by the production of the oxygen carrier and also the thermodynamic performances of the technology. It was noted in [11] that the environmental impact is strongly dependent on the plant thermodynamic efficiency and from this perspective is more interesting to use a combined cycle with a pressurised CLC reactor than an atmospheric reactor which can be coupled only to a steam turbine and has a lower efficiency. Besides this the duration of the oxygen carrier affect also in an important way the environmental impact of the plant. In fact, the oxygen carrier is interested by attrition and reactivity losses. To avoid that the oxygen carrier duration has a negative impact on the environment a duration of 4000 hours is suggested by the authors [11]. The basic data which is necessary to characterize the technology by an environmental and technical point of view are proposed in table 1 , taken from [11].

Table 1. Technical parameters CLC plant (800 MW plant) [11].

\begin{tabular}{|c|c|c|c|}
\hline Stage & Material & Value & Unit \\
\hline \multirow{4}{*}{$\begin{array}{c}\text { Plant } \\
\text { Construction }\end{array}$} & Concrete & 128.25 & $\mathrm{t} / \mathrm{MW}$ \\
\cline { 2 - 4 } & Steel & 40.9 & $\mathrm{t} / \mathrm{MW}$ \\
\cline { 2 - 4 } & Aluminium & 0.4 & $\mathrm{t} / \mathrm{MW}$ \\
\cline { 2 - 4 } & Iron & 0.4 & $\mathrm{t} / \mathrm{MW}$ \\
\hline \multirow{3}{*}{$\begin{array}{c}\text { Plant } \\
\text { operation }\end{array}$} & OC Flow & 5988 & $\mathrm{kmol} / \mathrm{s}$ \\
\cline { 2 - 4 } & OC Duration & 1315 & $\mathrm{~kg} / \mathrm{s}$ \\
\hline
\end{tabular}

An interesting information presented in the table 1 is the Oxygen Carrier (OC) duration we can see in fact that the iron oxygen carrier is assumed to last for about 1315 hours, while if we consider the nickel oxygen carrier this can last up to 10,000 hours. In the choice of the oxygen carrier it has also to be taken into consideration the price of the oxygen carrier and also its availability and impact (for example nickel carbon footprint is about 11.4 $\mathrm{kgCO} 2 \mathrm{eq} / \mathrm{kg}$ versus the $1.16 \mathrm{kgCO} 2 \mathrm{eq} / \mathrm{kg}$ iron) [11].

\subsection{Comparison of net electrical efficiencies, of competing technologies: Chemical Looping Combustion, Hydrogen Combined Cycle and Oxyfuel NGCC}

Singh et al. 2011 [2] present an interesting work on Comparative life cycle environmental assessment of Carbon Capture and Storage (CCS) technologies. They analyse in particular two fuels: coal and natural gas. For each of them three solutions are taken into account: 
capture in post combustion; capture in pre-combustion and capture through oxyfuel combustion.

In this paper we take into consideration the results of the base case, so conventional NGCC, as shown in table 2, and also the results of the oxyfuel combustion (oxy-NGCC). Application of oxyfuel combustion in power plant implies reduction in net efficiency due to energy requirement of the air separation unit (ASU). In the natural gas oxyfuel combustion system, an efficiency loss of $11.3 \%$ can be assumed [13], due to energy allowance for ASU. In table 2 the 4 cases of interest are considered: the baseline case is represented by conventional NGCC plant (representative also of the Italian CC plants); the CLC combustor integrated with a NGCC, the pre-combustion CCS (see $\mathrm{H}_{2}-\mathrm{CC}$ ), the oxy-combustion CCS (see oxy-NGCC).

Table 2. Electrical efficiency, $\mathrm{CO}_{2}$ capture efficiency and energy penalty of different Combine Cycle upgrading technologies.

\begin{tabular}{|c|c|c|c|c|}
\hline Stage & $\begin{array}{c}\text { Electrical } \\
\text { Efficiency }\end{array}$ & $\begin{array}{c}\mathrm{CO}_{2} \text { capture } \\
\text { Efficiency }\end{array}$ & $\begin{array}{c}\text { Energy } \\
\text { Penalty }\end{array}$ & Source \\
\hline NGCC & $58.1^{*}$ & $0 \%$ & $0 \%$ & {$[2]$} \\
\hline CLC-NGCC & $45.7 \%$ & $97 \%$ & $12.4 \%$ & {$[11]$} \\
\hline H2-CC & $57.7 \%$ & NA & $0.4 \%$ & {$[14]$} \\
\hline Oxy-NGCC & $46.8 \%$ & $90 \%$ & $11.3 \%$ & {$[2]$} \\
\hline
\end{tabular}

This means that together with the baseline case and the oxyfuel combustion case we introduce in this work the CLC coupled with NGCC, where main data are taken from the abovementioned study of Fan et al. 2018 [11], and also the H2-CC (this means a combined cycle powered by hydrogen). Dealing with CC powered by $100 \%$ hydrogen, this is an emerging technique which is thought to enter the market in the next years, an example is represented by the Vattenfall's Magnum GTCC plant (440 MW) in the Netherlands which will be reconverted by MHPS from natural gas to hydrogen in 2025 [15]. Also Fusina power plant in Italy was fired with hydrogen from 2010 to 2018 (16 MW, efficiency estimated to be $43 \%$, employing a GE10-1 type, single shaft, 11 compressor stages, 3 turbine stages) [16]. More than $75 \mathrm{GE}$ gas turbines have operated on fuels containing hydrogen, accumulating more than 5 million operating hours. An example of hydrogen fleet leader can be considered a Frame 6B unit at the Daesan petrochemical plant in Korea, which was installed in 1997 and is routinely running with hydrogen concentrations between 85\% and 97\% [16]. Also the HYFLEXPOWER goes in this direction [17]. Table 3 shows the main models of gas turbines which have been tested till now. Not all the producers have reached $100 \% \mathrm{H} 2$ combustion but they are approaching to it very fast. So it can be considered a feasible and soon marketable technology.

The European Turbine Network (ETN) report on Hydrogen Gas Turbines [18]. From that report we can understand that there are turbines which can run on high concentrations of

* (IEA, 2008). 
hydrogen, as reported in table 3. An efficiency of $57.7 \%$ is supposed for the $\mathrm{CC}$, according to Chiesa et al. 2005 [14].

Table 3. Gas Turbines models designed to run on $\mathrm{H} 2$ [18].

\begin{tabular}{|c|c|c|}
\hline Company & Turbines models & $\% \mathrm{H}_{2}$ \\
\hline \multirow{4}{*}{ Ansaldo } & GT36 H & $0-50 \%$ \\
\cline { 2 - 3 } & GT26 F & $0-45 \%$ \\
\cline { 2 - 3 } & E94.3A F-class & $0-25 \%$ \\
\cline { 2 - 3 } & GE 6B/7E/9E* & $0-35 \%$ \\
\hline \multirow{4}{*}{ BH } & E and F-class machines* & $0-40 \%$ \\
\cline { 2 - 3 } & GE10-1 & $0-100 \%$ \\
\hline \multirow{4}{*}{ GE } & Aeroderivative, B/E Class, F-Class, HA- & $0-100 \%$ \\
\cline { 2 - 3 } & Class & $0-100 \%$ \\
\cline { 2 - 3 } & Nova-LT & $85 \%$ \\
\cline { 2 - 3 } & Aeroderivative & $100 \%$ \\
\cline { 2 - 3 } & B/E-class & $65 \%$ \\
\hline Mann & F-class & $50 \%$ \\
\hline \multirow{3}{*}{ MHPS } & HA Class & $0-60 \%$ \\
\cline { 2 - 3 } & THM & $0-30 \%$ \\
\cline { 2 - 3 } & Multi-nozzle combustor & $0-90 \%$ \\
\hline \multirow{4}{*}{ Siemens } & Multi-cluster combustor & $0-100 \%$ \\
\cline { 2 - 3 } & Diffusion combustor & $0-30 \%$ \\
\cline { 2 - 3 } & Aeroderivative & $0-60 \%$ \\
\cline { 2 - 3 } & Utility gas turbines & $0-30 \%$ \\
\cline { 2 - 3 } & SGT-600 to SGT-800 & $0-60 \%$ \\
\hline Solar Turbines & SGT-100 and SGT-300 & \\
\hline *retrofitted & SGT-400 & \\
\hline
\end{tabular}

\subsection{Natural Gas Combined Heat and Power plants (NGCC plants) in the framework of the Italian National Energy Policy}

The latest Italian National Energy Strategy (SEN 2017) [19] aims at increasing the penetration of renewable energy in Italy. Part of the polices developed to support Energy Transition in Italy is also present in the Proposal of the National Integrated Plan for Energy and Climate [20]. Energy planning in Italy at a governmental level is based of the Italian Energy System simulations performed with the Times-Italia model developed by the Italian National Agency for New Technologies, Energy and Sustainable Economic Development [21]. While the Italian commitments on renewable energies are quite clearly expressed in the SEN it is very probable that the current NGCC plants, see figure 3 and figure 4, will remain strategic as well.

Figure 3 presents the locations of the existing NG power plants in Italy, as derived from the Global Power Plants Database. In red we see the CC in blue the gas turbines and in green the IGCCs. Figure 4 presents the power plants capacities. We see that the average capacity is about $677 \mathrm{MW}$ with a standard deviation of $549 \mathrm{MW}$, this means that the power capacity changes quite a lot. The maximum capacity is represented by the Montalto power station 
(also known as Alessandro Volta power station), which is a multifuel power plant mainly used as CC.

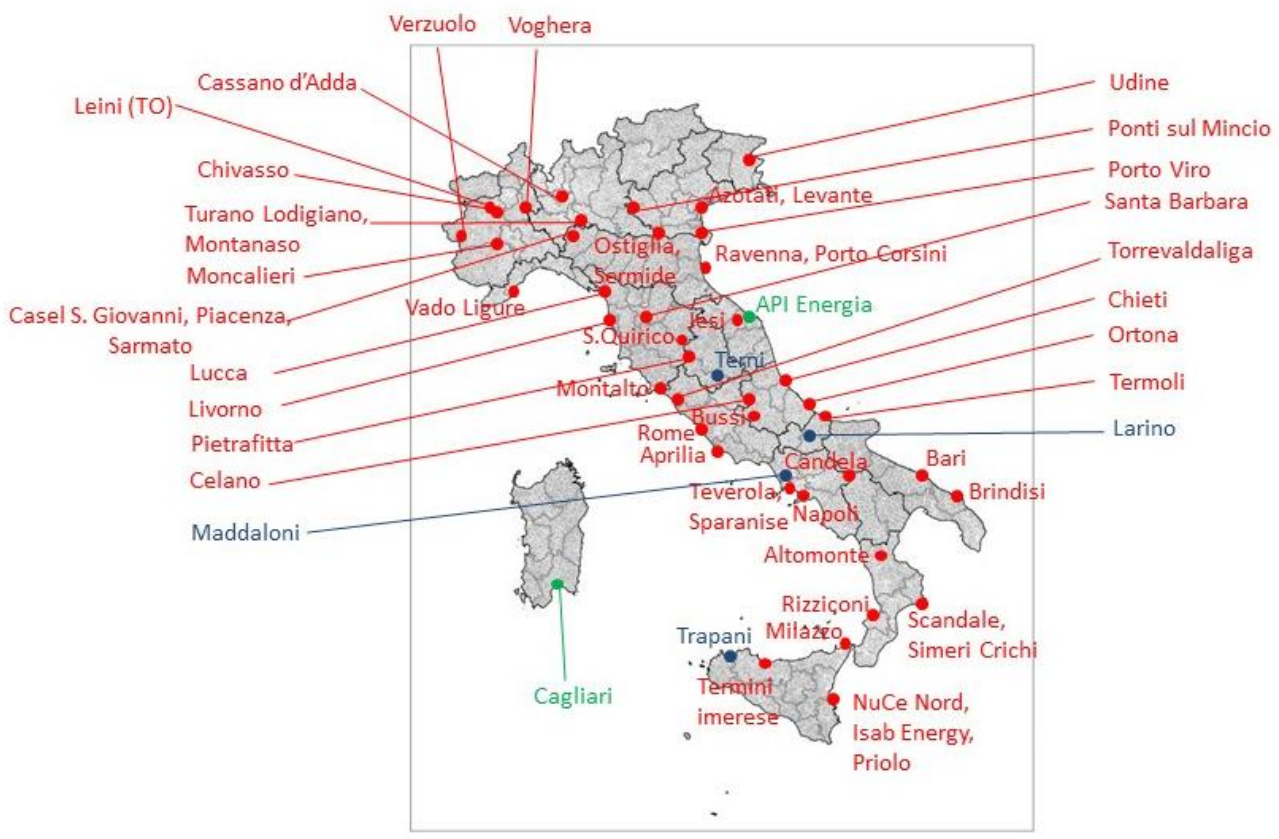

Fig. 3. Italian NGGT plants according to the Global Power Plants Database, [6]

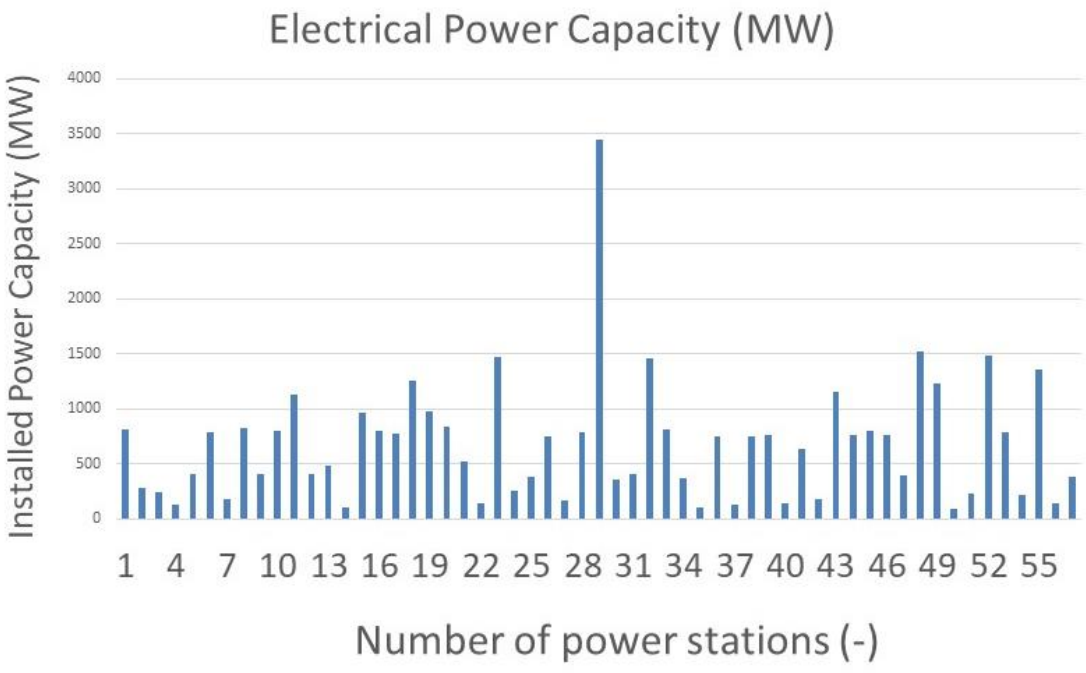

Fig. 4. Italian NGGT power plants capacities [6].

We can reasonably assume that the existing NGCC plants will be used to cover the base load demand of electricity. The final energy mix referred to 2030 is presented in figure 4 . 
We can see that, according to the SEN, the total renewable electricity production will be about $184 \mathrm{TWh}$ per year, while the electricity production from natural gas is assumed to be about $120 \mathrm{TWh}$ (to make calculations easier in this case we have added the electricity produced from natural gas - which is equal to $118 \mathrm{TWh}$ to the electricity produced from other oil derivates - which is equal to $2 \mathrm{TWh}-$ ).

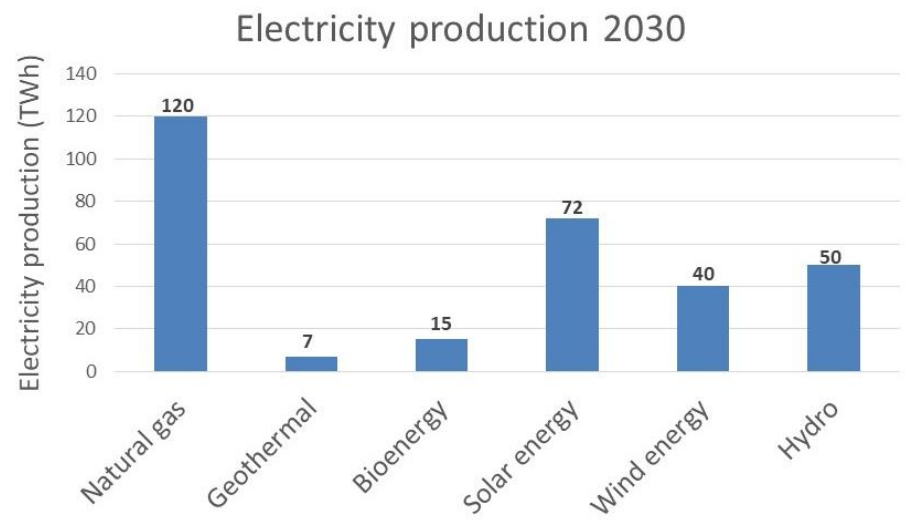

Fig. 5. Italian energy mix in 2030, according to SEN [19].

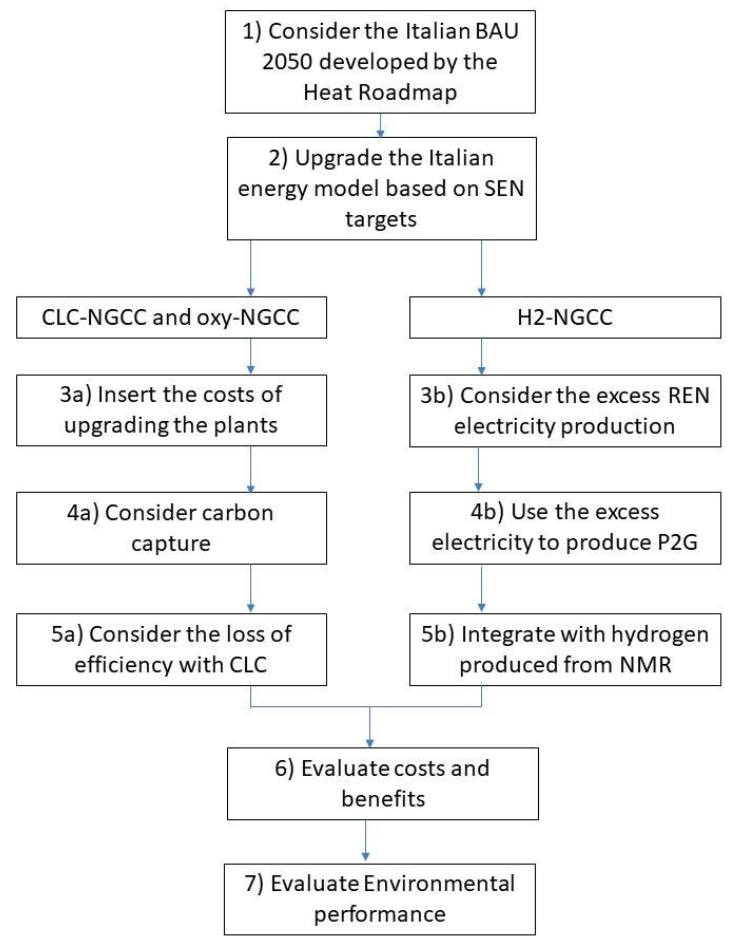

Fig. 6. Integration of EnergyPlan with LCA, methodology. 
To improve further the reduction of GHG emissions it can be interesting to gradually upgrade the NGCC plants to new and more clean technologies, as those presented in table 2: CLC combustors, oxy-fuel combustors and also $\mathrm{H} 2$ gas turbines are still in development we can compare the convenience of introducing these technologies to upgrade existing CC power plants in 2030. This is done with the methodology considered in figure 4 . The different scenarios are implemented in the software EnergyPlan. finding the total investment costs of the system and also the total $\mathrm{CO}_{2}$ emissions. The above mentioned software has been developed by the university of Aalborg in Denmark [22] and it is used to model energy systems at a national, regional or local level to develop smart energy systems based on high renewable energy penetration. To build a model in the EnergyPlan software [22] a relevant part is the collection of the required data. For this aim in this study we have referred to the Italian energy model 2010 and the business-as-usual model 2050 [23]. These have been updated and calibrated to 2030 using the targets set in the SEN and reported in figure 5 .

\subsection{Attributional LCA analysis on the technologies to upgrade NGCC power plants}

LCA analysis is based on ISO 14040 and ISO 14044 norms. The Goal of the analysis is "to provide information on the impact (and more specifically on the carbon footprint) of cleaner technologies used to upgrade existing NGCC". Where for cleaner technologies we intend those presented in table 2. For NGCC power plants attributional analysis the PCR developed in 2007 (version 4, valid until 2024) by the International EPD system (Environdec) [24]: "ELECTRICITY, STEAM AND HOT WATER GENERATION AND DISTRIBUTION PRODUCT CATEGORY CLASSIFICATION: UN CPC 171, 173” was adopted. Dealing with the Scope of the study, the following assumptions are made:

- the functional unit is set to be: electricity production;

- the reference flow is set to be $1 \mathrm{MWh}$;

- the system boundaries are shown in Figure 7.
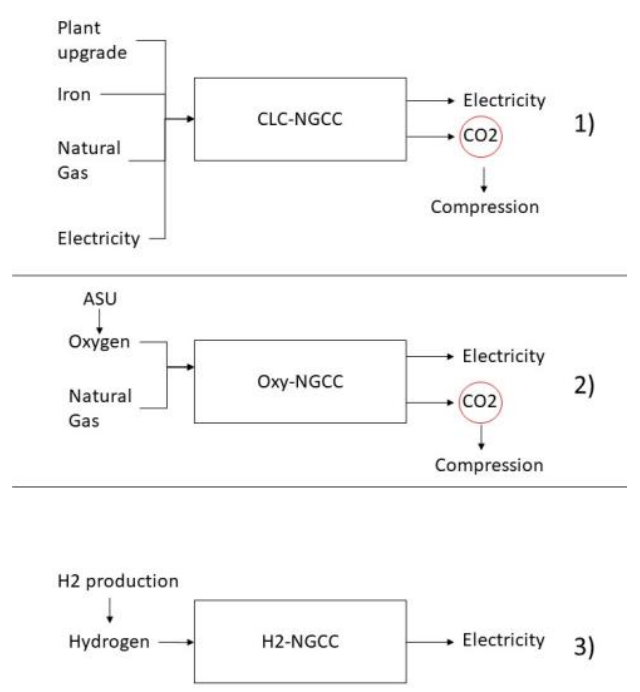

Fig. 7. Coupled NGGT and CLC combustor. 
Table 4. Emission factors and mass rations coefficients used in the study[18].

\begin{tabular}{|c|c|c|c|}
\hline \multirow[t]{2}{*}{ Process } & \multicolumn{3}{|c|}{ Parameter } \\
\hline & Value & Unit & Source \\
\hline *SMR H2 & 12.13 & $\mathrm{kgCO}_{2} \mathrm{eg} / \mathrm{kg}$ & {$[26]$} \\
\hline${ }^{*} \mathrm{CG} \mathrm{H} 2$ & 24.2 & $\mathrm{kgCO}_{2} \mathrm{eq} / \mathrm{kg}$ & [26] \\
\hline *BMG H2 & 2.67 & $\mathrm{kgCO}_{2} \mathrm{eq} / \mathrm{kg}$ & [26] \\
\hline *BDL-E-Corn H2 & 9.193 & $\mathrm{kgCO}_{2} \mathrm{eq} / \mathrm{kg}$ & [26] \\
\hline *BDL-E-Wheat H2 & 14.02 & $\mathrm{kgCO}_{2} \mathrm{eq} / \mathrm{kg}$ & [26] \\
\hline *E-PEM & 29.54 & $\mathrm{kgCO}_{2} \mathrm{eq} / \mathrm{kg}$ & [26] \\
\hline *E-PEM-R & 2.21 & $\mathrm{kgCO}_{2} \mathrm{eq} / \mathrm{kg}$ & [26] \\
\hline$*$ E-SOEC & 23.32 & $\mathrm{kgCO}_{2} \mathrm{eq} / \mathrm{kg}$ & [26] \\
\hline *E-SOEC-R & 5.10 & $\mathrm{kgCO}_{2} \mathrm{eq} / \mathrm{kg}$ & [26] \\
\hline${ }^{*}$ DF-MEC w/out R & 16.29 & $\mathrm{kgCO}_{2} \mathrm{eq} / \mathrm{kg}$ & [26] \\
\hline *DF-MEC w/ER & 6.60 & $\mathrm{kgCO}_{2} \mathrm{eq} / \mathrm{kg}$ & [26] \\
\hline $\begin{array}{c}\text { *DF-MEC w/H2 } \\
\text { Recovery }\end{array}$ & 14.57 & $\mathrm{kgCO}_{2} \mathrm{eq} / \mathrm{kg}$ & [26] \\
\hline Methane Production & 1.64 & $\mathrm{kgCO}_{2} \mathrm{eg} / \mathrm{kg}$ & ELCD \\
\hline Iron Oxide & 1.16 & $\mathrm{kgCO}_{2} \mathrm{eq} / \mathrm{kg}$ & {$[11]$} \\
\hline Oxygen Production & 0.15 & $\mathrm{kgCO}_{2} \mathrm{eq} / \mathrm{kg}$ & [27] \\
\hline $\begin{array}{c}\text { Oxygen } \\
\text { consumption }\end{array}$ & 4.1 & $\mathrm{kgO}_{2} / \mathrm{kgCH}_{4}$ & [28] \\
\hline $\begin{array}{l}\text { Hydrogen } \\
\text { consumption }\end{array}$ & 0.05 & $\mathrm{kgH}_{2} / \mathrm{kWh}$ & {$[14]$} \\
\hline Steel & 1.9 & $\mathrm{kgCO}_{2} \mathrm{eq} / \mathrm{kg}$ & ELCD \\
\hline Concrete & 0.9 & $\mathrm{kgCO}_{2} \mathrm{eq} / \mathrm{kg}$ & {$[3]$} \\
\hline Methane combustion & 0.64 & $\mathrm{kgCO}_{2} / \mathrm{kWh}$ & [30] \\
\hline Electricity mix IT & 0.38 & $\mathrm{kgCO}_{2} \mathrm{eq} / \mathrm{kWh}$ & $\begin{array}{c}\text { Ecoinvent } \\
3.4\end{array}$ \\
\hline \multicolumn{4}{|c|}{$\begin{array}{l}\text { * SMR: Steam methane reforming; CG: Coal gasification; BMG: Biomass Gasification; } \\
\text { BDL: Biomass Reformation; E-PEM: Electrolysis with Proton exchange membrane (PEM): } \\
\text { E-PEM-R: Electrolysis with Proton exchange membrane with wind energy; E-SOEC: } \\
\text { Electrolysis with Solid oxide electrolysis cells (SOEC); E-SOEC-R: Electrolysis with Solid } \\
\text { oxide electrolysis cells with wind energy; DF-MEC: Dark fermentation + microbial } \\
\text { electrolysis cell (MEC) without energy recovery, with energy recovery and } \mathrm{H}_{2} \text { recovery. }\end{array}$} \\
\hline
\end{tabular}

The system boundaries and the detailed analysis of a conventional NGCC is contained in the recent report prepared by Energy Sector Planning and Analysis (ESPA) for the United States Department of Energy (DOE), National Energy Technology Laboratory (NETL) [3]. As far as the Life Cycle Impact assessment method is concerned it is assumed to consider only the release of GHG. The release of other polluting emissions which are also of interest, like NOx emissions, will be object of further research works. This will be particularly important for hydrogen fed CCs, but on this topic still much research is ongoing. From figure 7 we can see that the main impact for the CLC plant is given by: plant upgrading, the use of the oxygen carrier (which in this study is supposed to be iron oxide), electricity consumption and also natural gas consumption. This last parameter is the input of 2 out of 3 scenarios and its consumption depends on the efficiency of the plant itself. Together with the electricity consumption necessary to grant the operation of the different power plants, also $\mathrm{CO}_{2}$ compression is considered at least for the 1 st and 2 nd scenarios. In the $3 \mathrm{rd}$ scenario the compression of $\mathrm{CO}_{2}$ is not needed. In the second scenario the electricity consumption is needed also for the operation of the ASU and the production of pure oxygen from air. Also the ASU infrastructure has to be considered in this case. For the third scenario it is worth noting that the impact of hydrogen production varies importantly 
depending on the chosen technology. We provide some emission factors of the main processes considered in the life cycle of the 3 proposed plants in table 4 .

Dealing with hydrogen production, we see that the carbon footprint can vary importantly depending on the chosen technology, the average value is about 13.43 with a standard deviation of 8.8. We assume dealing with hydrogen production to use $\mathrm{P} 2 \mathrm{G}$ deploying the renewable power which is overproduced by wind and solar. This is a favourable case indicated by E-PEM-R and E-SOEC-R. For this reason, we believe that the average of the two emission factors should be considered. The advantage of integrating excess electricity in the production of hydrogen with a $\mathrm{P} 2 \mathrm{G}$ system anyway can be fully understand by integrating the results of the EnergyPlan software with those of Input-Output Life Cycle Assessment (IO-LCA). This is because attributional LCA analysis usually refers to a single plant while in this case it is worthy to considerate the effect on the whole country energy mix.

\subsection{IO-LCA analysis on the Italian power sector}

We find statistics on the Italian power sector not only in the IEA statistics, in the EUROSTAT statistics, in the Transmission Network Operator (Terna) statistics and in the strategies developed by the Italian Ministry of Economics, but also in the IO tables on Italian economics developed by the National Institute of Statistics and most of all in the IO tables of the EXIOBASE database. This is a global, detailed Multi-regional Environmentally Extended Supply and Use / Input Output (MR EE SUT/IOT) database developed during different European projects mainly by TNO Netherlands, Institute of Environmental Sciences (CML) of Leiden University, the Industrial Ecology Programme at NTNU, SERI Vienna, Wuppertal Institute for Climate, Environment and Energy (Germany), 2.-0 LCA consultants (Denmark) and many others [31-34].

In this case we have considered the EXIOBASE version 3 hybrid. This can be downloaded from the website of the project and is base on the concept of physical supply and use tables [1] as defined in the Systems of Economic and Environmental Accounts (SEEA) [36]. Together with the supply and use tables also another file called "extensions" is provided and this contains mainly the consumption of resources, the emissions, the consumption of land and many other information. In particular we have focused our attention on the emissions referred to the demand. Assuming that the demand of energy is full satisfied by the country production we have referred the emissions to the unit of energy demand. In this way the coefficients derived in table 5 were obtained.

Table 5. Carbon footprints of Electricity produced with different technologies.

\begin{tabular}{|c|c|c|c|c|}
\hline Energy Source & Emissions $\left(\mathrm{tCO}_{2}\right)$ & Production (TJ) & $\begin{array}{c}\text { Emission } \\
\text { Factor }\end{array}$ & Unit \\
\hline Coal & $39,565,913$ & 155047 & $9.18 \mathrm{E}-01$ & $\mathrm{tCO}_{2} \mathrm{eq} / \mathrm{MWh}$ \\
\hline Gas & $64,614,228$ & 477055 & $4.87 \mathrm{E}-01$ & $\mathrm{tCO}_{2} \mathrm{eq} / \mathrm{MWh}$ \\
\hline Hydro & 2,740 & 156348 & $6.30 \mathrm{E}-05$ & $\mathrm{tCO}_{2} \mathrm{eq} / \mathrm{MWh}$ \\
\hline Wind & 337 & 34106 & $3.55 \mathrm{E}-05$ & $\mathrm{tCO}_{2} \mathrm{eq} / \mathrm{MWh}$ \\
\hline Petroleum \& other & $13,190,600$ & 62265 & $7.62 \mathrm{E}-01$ & $\mathrm{tCO}_{2} \mathrm{eq} / \mathrm{MWh}$ \\
\hline Biomass & 92 & 11583 & $2.87 \mathrm{E}-05$ & $\mathrm{tCO}_{2} \mathrm{eq} / \mathrm{MWh}$ \\
\hline PV & 3 & 37360 & $3.05 \mathrm{E}-07$ & $\mathrm{tCO}_{2} \mathrm{eq} / \mathrm{MWh}$ \\
\hline Geothermal & 449 & 18948 & $8.52 \mathrm{E}-05$ & $\mathrm{tCO}_{2} \mathrm{eq} / \mathrm{MWh}$ \\
\hline $\begin{array}{c}\text { Electricity } \\
\text { Transmission }\end{array}$ & 859 & 1990 & $7.34 \mathrm{E}-06$ & $\mathrm{tCO}_{2} \mathrm{eq} / \mathrm{MWh}$ \\
\hline $\begin{array}{c}\text { Electricity } \\
\text { Distribution }\end{array}$ & 3,5043 & 22620 & $2.63 \mathrm{E}-05$ & $\mathrm{tCO}_{2} \mathrm{eq} / \mathrm{MWh}$ \\
\hline
\end{tabular}


The emission factor reported in table 5 are in agreement with those reported in [37].

\section{Results}

\subsection{Results of the Energy Scenarios}

Base on the data reported in the SEN and also in the existing Italian case study accessible in the EnergyPlan website three scenarios for upgrading the NGCC sector are proposed and compared with the baseline scenario:

- CLC-NGCC, the upgrading of the plant inserting a Chemical Looping Combustor to substitute the turbine combustion chamber;

- the substitution of natural gas with hydrogen (H2-CC);

- the implementation of oxyfuel combustion in the gas turbine.

For each scenario has been evaluated the costs of the upgrading operation and a simulation has been run using EnergyPlan software. The economic costs of the 4 compared scenarios are reported in Figure 7.

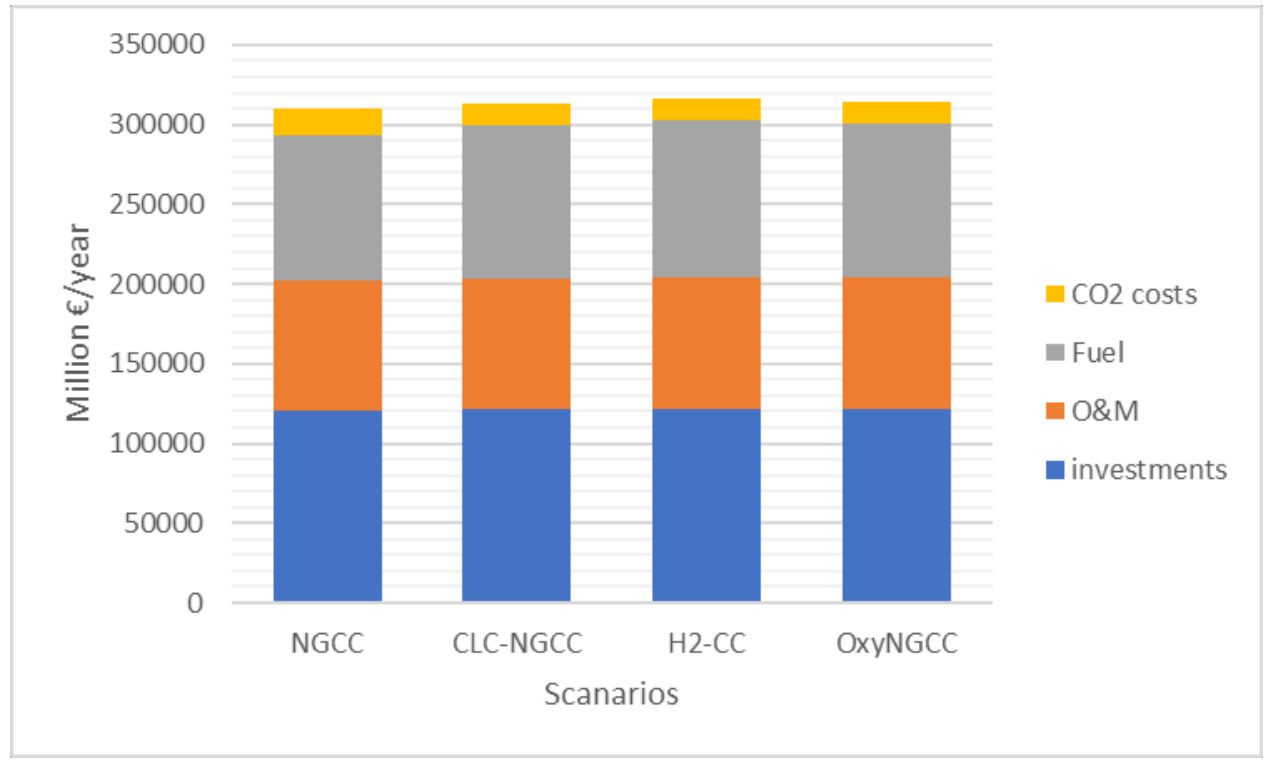

Fig. 8. Coupled NGGT and CLC combustor.

- $\quad$ As we see from figure 7 all the 3 NGCC upgrading scenarios are quite similar to the annual expense of the current NGCC system. We have to think that to installing a CLC combustor in a combined cycle the biggest investment is that necessary for the fluidised beds on which the plant is based but this expense is not so high (it is evaluated to 200,000 € for two fluidised bed reactors, more compact reactors and maybe with a lower cost are under study [38]). Then the variable expenses will increase due to need of using the oxygen carriers. Another expense which is needed for the CLC-NGCC and the oxyNGCC is the compression of $\mathrm{CO} 2$ storage, this will have an important impact on the economic costs. 
This cost was taken from [39]. Being the results so similar, the difference is due to small particulars, such as the cost of $\mathrm{CO} 2$ emissions. In this case it is forecasted a cost of about 47 $€ / \mathrm{tCO} 2$ this is based on [40].

- Concerning H2-CC not only the gas turbines of the combined cycles have to be slightly upgraded, but the power plants need an infrastructure which can provide the hydrogen at reasonable costs. An option can be represented by the production of hydrogen through power to gas technologies. For this reason we have used the EnergyPlan section on electrofuels assuming to employ the excess electricity produced by wind and solar PV to produce hydrogen through electrolysers (we have assumed the electrofuel is made $100 \%$ by hydrogen and so no $\mathrm{CO} 2$ reduction is performed). The point is that to produce all the hydrogen needed in one year the excess electricity is obviously not sufficient so in this way some more electricity should be imported by the country. The comparison between the annual imports of electricity in the 3 compared cases is shown in figure 8 .

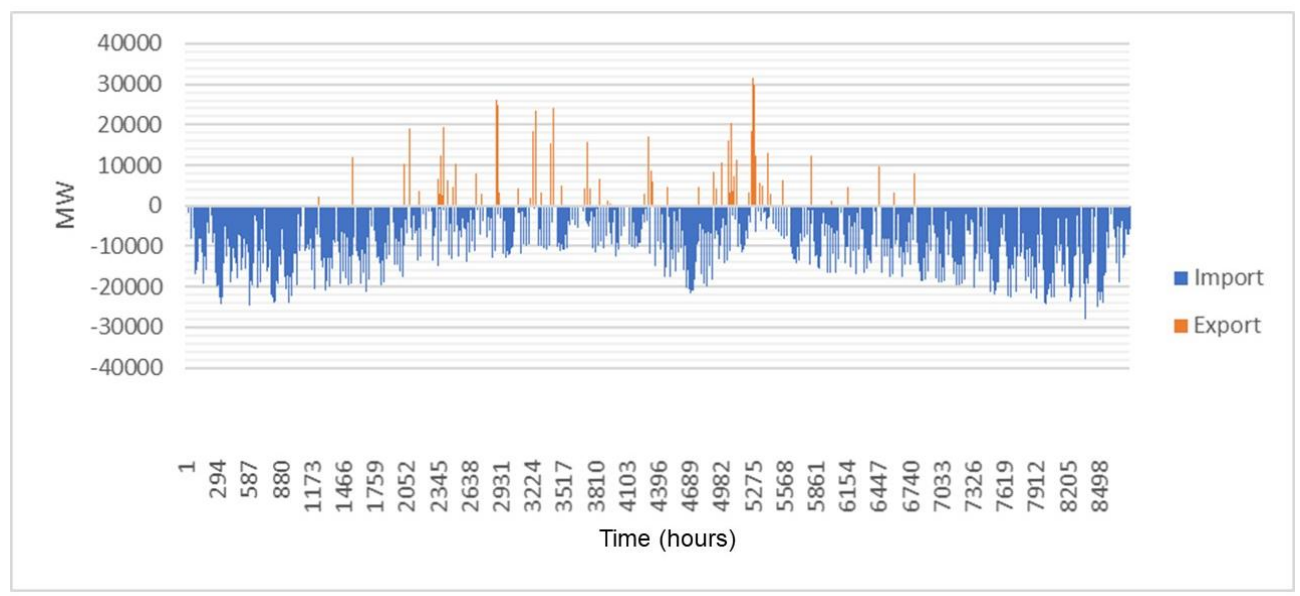

Fig. 9. Import export of electricity in the case of $\mathrm{H}_{2}-\mathrm{CC}$, referred to the Country of Italy.

The $\mathrm{H}_{2}-\mathrm{CC}$ case is the only in which the balance between import and export is different from 0 (that was the assumption made for the model).

For the oxy-NGCC scenario the cost are the highest. This is due to the reduced readiness of the technology and also to the important costs of the ASU both for initial investment and also for maintenance and operation.

\subsection{Results of the Environmental Analysis}

The results of the preliminary attributional LCA study are proposed in table 6 . We can see that the emissions of the NGCC plant are about $450 \mathrm{kgCO} 2 \mathrm{eq} / \mathrm{MWh}$ of electricity produced. These are quite similar to the one reported in [3]. The emissions of the CLCNGCC are similar to those reported in [11]. 
Table 6. Carbon footprints of Electricity produced with different technologies.

\begin{tabular}{|c|c|c|c|}
\hline Process & \multicolumn{3}{|c|}{ GHG Emissions } \\
\hline & Value & Literature & Unit \\
\hline NGCC & 450 & $485.1[3]$ & $\mathrm{kgCO} 2 \mathrm{eq} / \mathrm{MWh}$ \\
\hline CLC-NGCC & 65.1 & $69.4[11]$ & $\mathrm{kgCO} e q / \mathrm{MWh}$ \\
\hline H2-CC & 150 & $\mathrm{NA}$ & $\mathrm{kgCO} 2 \mathrm{eq} / \mathrm{MWh}$ \\
\hline Oxygen & 111 & $120[2] \dagger$ & $\mathrm{kgCO} \mathrm{eq} / \mathrm{MWh}$ \\
\hline
\end{tabular}

Maybe due to the reduced availability of commercial H2-CC plants the carbon footprint of one MWh produced in a combined cycle power plant using hydrogen is not available. The value we calculated is mainly due to the production of hydrogen (which was assumed to be done with an electrolyser powered by electricity produced with wind or solar PV). Dealing with the carbon footprint of $1 \mathrm{MWh}$ produced with oxy-NGCC this can be reduced in the future. In fact in the work of Fernandes et al. 2019 it is shown that the Allam cycle can be a promising solution to further reduce the carbon footprint of electricity production [41]. The contributions of each life cycle process to the total carbon footprint is shown in figure 9.

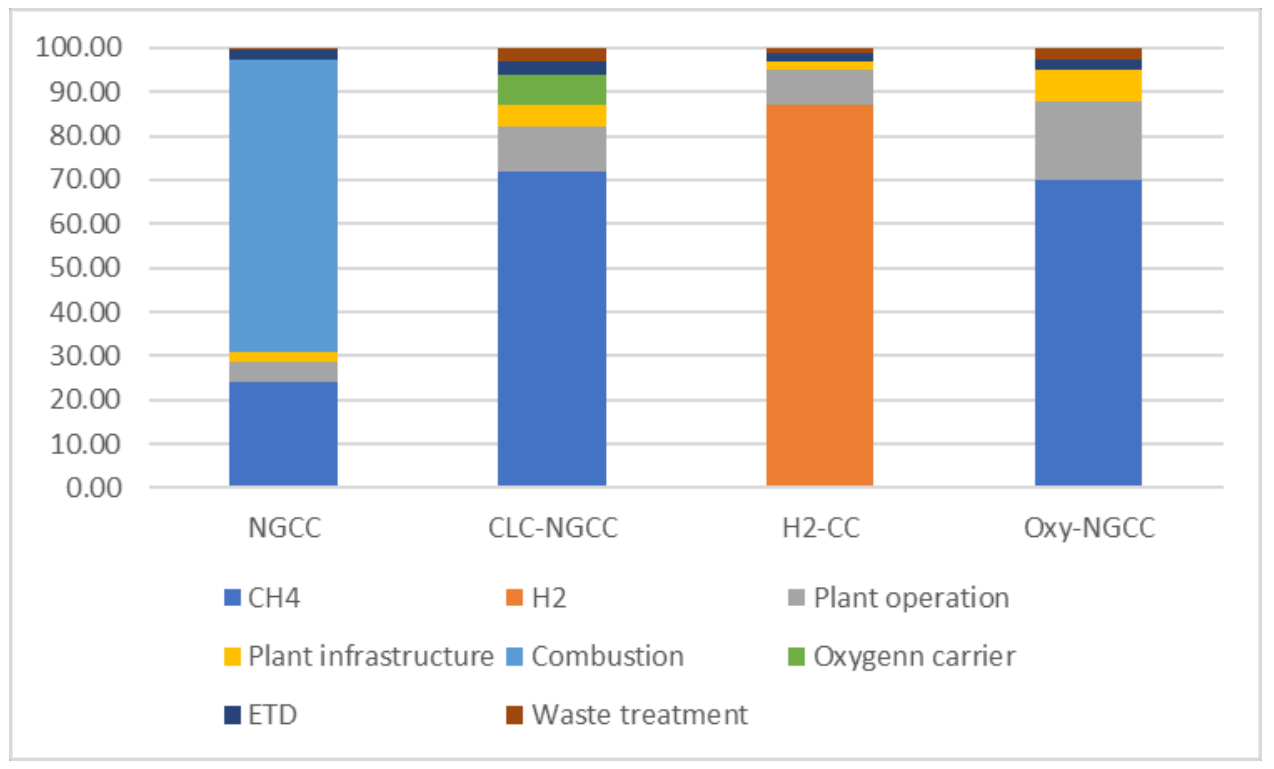

Fig. 10. Contribution analysis on the impact of the different life cycle processes on the electricity carbon footprint.

As it can be seen from figure 10, the fuel contributes always to more than $50 \%$ of the total carbon footprint in all the three technologies to upgrade the NGCC, while in the conventional plants the carbon footprint is still dominated by the combustion process.

\footnotetext{
$\dagger$ Process and Carbon Footprint Analyses of the Allam

Cycle Power Plant Integrated with an Air

Separation Unit
} 


\subsection{IO-LCA analysis based on the results of EnergyPlan model}

In the original intention the IO-LCA was applying the coefficients shown in table 5 and taken from the EXIOBASE 3 (hybrid) but while the emissions obtained for the fossil fuels were reasonable, a discrepancy with literature was detected for the Reenable energy production GHG emissions.

So for this reason for the renewable energy production the emission factors taken from [4244] were finally chosen. These are the following:

- geothermal: $40 \mathrm{kgCO}_{2} \mathrm{eq} / \mathrm{MWh}$ _e;

- bioenergy: $240 \mathrm{kgCO}_{2}$ eq/MWh_e;

- solar PV: 70 kgCO 2 eq/MWh_e;

- wind: $7 \mathrm{kgCO}{ }_{2} \mathrm{eq} / \mathrm{MWh}$ e;

- hydro: $20 \mathrm{kgCO}_{2} / \mathrm{MWh} \mathrm{e}$;

For the natural gas CC plants the value of $487 \mathrm{kgCO}_{2} \mathrm{eq} / \mathrm{MWh}$ e was chosen, as reported in table 5, the choice was done because the value is specific of the average emissions of the sector and it is specific of Italy.

The emission factors for the other three upgrading technologies (i.e. Chemical Looping Combustion; oxyfuel combustion and hydrogen combustion) for the natural gas combined cycle power plants were chosen, referring to the values reported in table 6 . So the results of the attributional LCA were used as a reference for the average Italian power sector.

The emission factors were applied to the final energy outputs given by the EnergyPlan software and the results are shown in figure 11.

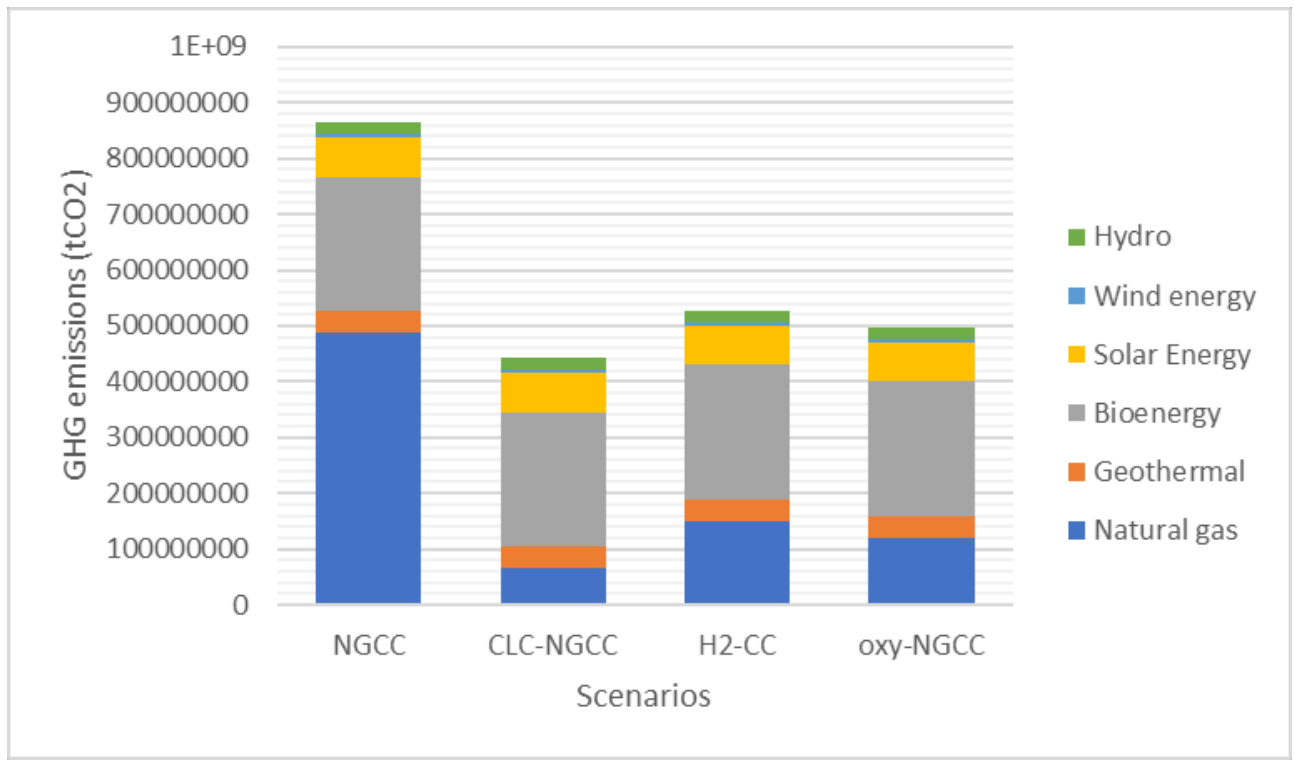

Fig. 11. Contribution analysis on the impact of the different life cycle processes on the electricity carbon footprint.

Figure 10 shows that the emissions reduction which can be obtained with the different technologies compared in this study are the following:

- $422 \mathrm{MtCO}_{2}$ can be reduced by upgrading NGCC to CLC-NGCC (reduction of 49\%);

- $337 \mathrm{MtCO}_{2}$ can be reduced by upgrading $\mathrm{NGCC}$ to $\mathrm{H}_{2}-\mathrm{CC}$ (reduction of $39 \%$ ); 
- $367 \mathrm{MtCO}_{2}$ can be reduced by upgrading NGCC to oxy-NGCC (reduction of $42 \%$ ).

Dealing with the total emissions amount shown for the business-as-usual case (which is the conventional NGCC) this is about $864 \mathrm{MTCO}_{2}$. If we consider the Italian national inventory of GHG it reports that in 2016 the emissions due to the entire power sector were $335 \mathrm{MtCO}_{2}$. So this means that if the emissions are calculated in the entire life cycle of the power plants these can be 2.6 higher.

\section{Conclusions}

Economic and environmental analysis have been applied to the comparison of three possible technologies to be used to upgrade NGCC power plants in Italy. The first technology taken into account is Chemical Looping Combustion which by combusting the natural gas with oxygen carriers (instead of gaseous oxygen) produces a pure stream of $\mathrm{CO}_{2}$ which can be easily captured and compressed (this technology is currently at TRL 6). The second technology is direct combustion of $100 \%$ hydrogen in the gas turbine combustion chamber (this technology is approaching the market now). The third technology is oxyfuel combustion of natural gas in gas turbines and then CCS. Also this last technology is approaching the market and it has been already tested for coal but for natural gas it needs more R\&D. The results show that all the considered technologies can have a high impact at relatively low investment cost. In fact the existing power facilities can be upgraded and don't require to be build ex-novo. This is an interesting advantage. The reduction on the GHG emissions released during the total life cycle of the entire power sector in Italy could be halved.

\section{Nomenclature}

Symbols in the manuscript should be included in a nomenclature list grouped into symbols, subscripts/superscripts, and acronyms/abbreviations with placement before the references.

\begin{tabular}{|c|c|c|}
\hline CLC & Chemical Looping Combustion & - \\
\hline CLC-NGCC & Coupled CLC combustor and NGCC & - \\
\hline H2-CC & Hydrogen fed Combined Cycle & - \\
\hline NG & Natural Gas & - \\
\hline NGCC & Natural Gas Combined Cycle & - \\
\hline Oxy-NGCC & Oxy-fuel Combustion NGCC & - \\
\hline P2G & Power to Gas & - \\
\hline SEN & Italian National Energy Strategy & - \\
\hline SMR & Steam Methane Reforming & - \\
\hline CG & Coal Gasification & - \\
\hline BMG & Biomass Gasification & - \\
\hline BDL-E-Corn & Reforming of Ethanol from corn & - \\
\hline BDL-E-Wheat & Proton Exchange Membrane & - \\
\hline E-PEM & wind energy & - \\
\hline E-PEM-R & Electrolysis with Proton Exchange membrane with & - \\
\hline E-SOEC & Electrolysis with Solid oxide electrolysis cells & - \\
\hline E-SOEC-R & Electrolysis with Solid oxide electrolysis cells with & - \\
\hline DF-MEC w/out R & wind energy & - \\
\hline & Dark fermentation + microbial electrolysis cell & \\
\hline
\end{tabular}




\begin{tabular}{|c|c|c|}
\hline DF-MEC w/ER & $\begin{array}{c}\text { Dark fermentation + microbial electrolysis cell with } \\
\text { energy recovery }\end{array}$ & - \\
\hline DF-MEC w/H2 Recovery & $\begin{array}{c}\text { Dark fermentation + microbial electrolysis cell with } \\
\text { H2 recovery }\end{array}$ & - \\
\hline
\end{tabular}

\section{Acknowledgments}

This work has been partially funded by the GTCLC-NEG project that has received funding from the European Union's Horizon 2020 research and innovation programme under the Marie SklodowskaCurie grant agreement No. 101018756.

\section{References}

1. IEA, World Energy Outlook 2017

2. European Commission, COM (2015) 80, Communication from the commission to the European parliament, the council, the european economic and social committee, the committee of the regions and the European investment bank, A Framework Strategy for a Resilient Energy Union with a Forward-Looking Climate Change Policy, https://www.eea.europa.eu/policy-documents/com-2015-80-final [Accessed: 2-June2020]

3. IEA, World Energy Outlook 2018.

4. EUROSTAT, Electricity production capacities for combustible fuels by technology and operator, https://appsso.eurostat.ec.europa.eu/nui/submitViewTableAction.do

5. TERNA \& SNAM; Documento di descrizione degli scenari 2019, https://download.terna.it/terna/DDS\%20libro\%2009\%2030\%2017h15_8d745ced8696c 60.pdf

6. Global Power Plant Database, https://datasets.wri.org/dataset/globalpowerplantdatabase

7. Zerobin, F., Penthor, S., Bertsch, O., Pröll, T., Fluidized bed reactor design study for pressurized chemical looping combustion of natural gas, Powder Technology, Vol. 316, pp. 569-577, 2017

8. Eret, P., A cost-effective compressed air generation for manufacturing using modified microturbines, Applied Thermal Engineering, Vol. 107, pp. 311-319, 2016.

9. IRENA, RENEWABLE ENERGY TECHNOLOGIES: COST ANALYSIS SERIES.

10. Khan, M.N., Chiesa, P., Cloete, S., Aminia, S., Integration of chemical looping combustion for cost-effective $\mathrm{CO} 2$ capture from state-of-the-art natural gas combined cycles, Energy Conversion and Management, in print, 2020.

11. Fan, J., Hong, H., Jin, H., Power Generation Based on Chemical Looping Combustion: Will It Qualify To Reduce Greenhouse Gas Emissions from Life-Cycle Assessment? ACS Sustainable Chem. Eng., Vol. 6, pp. 6730-6737, 2018.

12. Singh, B., Strømman, A.H., Hertwich, E.G., Comparative life cycle environmental assessment of CCS technologies, International Journal of Greenhouse Gas Control, Vol. 5, pp. 911-921, 2011.

13. Dillion, D.J., Panesar, R.S., Wall, R.A., Allam, R.J., White, V., Gibbins, J., Haines, M.R., Oxy-combustion processes for $\mathrm{CO} 2$ capture from advanced supercritical PF and NGCC power plant. In: Proceedings of 7th International Conference on Greenhouse Gas Control Technologies. Volume 1: Peer Reviewed Papers and Overviews, Elsevier Science, Oxford, UK, pp. 211-220. 2005. 
14. Chiesa, P., Lozza, G., Mazzocchi, L., Using Hydrogen as Gas Turbine Fuel, Journal of Engineering for Gas Turbines and Power, Vol. 127, pp.73-80, 2005.

15. MHPS, Hydrogen power generation handbook, https://www.mhps.com/catalogue/pdf/mhps_hydrogen_en.pdf

16. Fusina combined cycle project: planning to run on pure hydrogen, https://www.modernpowersystems.com/features/featurefusina-combined-cycle-projectplanning-to-run-on-pure-hydrogen/

17. https://www.power-eng.com/2020/06/01/siemens-engie-euro-universities-createhydrogen-gas-turbine-demonstrator-project/

18. European Turbine Network (ETN), Hydrogen Gas Turbine report, January 2020, https://etn.global/wp-content/uploads/2020/01/ETN-Hydrogen-Gas-Turbinesreport.pdf

19. MISE, MATTM. Strategia Energetica Nazionale. SEN; 2017. https://www.mise.gov.it/images/stories/documenti/Testo-integrale-SEN-2017.pdf

20. MISE, Proposta di Piano Nazionale Integrato per Energia e il Clima, 2018 https://www.mise.gov.it/images/stories/documenti/Proposta_di_Piano_Nazionale_Inte grato_per_Energia_e_il_Clima_Italiano.pdf

21. ENEA, Il modello energetico TIMES-Italia, 2011, http://opac22.bologna.enea.it/RT/2011/2011_9_ENEA.pdf

22. Mathiesen BV, Lund H, Connolly D, et al.. "Smart Energy Systems for coherent $100 \%$ renewable energy and transport solutions." Applied Energy (145): 139-154. 2015

23. Connolly, D., Hansen, K., Drysdale, D., Lund, H., Mathiesen, B. V., Werner, S., Persson, U., Möller, B., Wilke, O. G., Bettgenhäuser, K., Pouwels, W., Boermans, T., Novosel, T., Krajačić, G., Duić, N., Trier, D., Møller, D., Odgaard, A. M., Jensen, L. L. (Heat Roadmap Europe 3 and STRATEGO WP2 Main Report) Enhanced Heating and Cooling Plans to Quantify the Impact of Increased Energy Efficiency in EU Member States: Translating the Heat Roadmap Europe Methodology to Member State Level. Aalborg University, Halmstad University, University of Flensburg, Ecofys, University of Zagreb, and PlanEnergi, 2015. Available from: http://www.heatroadmap.eu.

24. https://www.environdec.com/PCR/Detail/?Pcr=5802

25. Skone, T.J., Schivley, G., Jamieson, M., Marriott, J., Cooney, G., Littlefield, J., Mutchek, M., Krynock, M., Shih, C., LIFE CYCLE ANALYSIS: NATURAL GAS COMBINED CYCLE (NGCC) POWER PLANTS, DOE Contract Number DEFE0025912, 2018

26. Mehmeti, A., Angelis-Dimakis, A., Arampatzis, G., McPhail, S.J., Ulgiati, S., Life Cycle Assessment and Water Footprint of Hydrogen Production Methods: From Conventional to Emerging Technologies, Environments, Vol. 5, 0; 2018

27. Oshima K., Uchiyama, Y., Performance and Economic Study of Oxy-fuel Gas Turbine Power Plant Utilizing Nuclear Steam Generator, Journal of Energy and Power Engineering, Volume 4, No.8 (Serial No.33), ISSN 1934-8975, 2010.

28. Ditaranto, M. 5th Meeting of the IEAGHG International OxyfuelCombustion Research Network, presentation, Wuhan, China, 2015

29. Riccardo Maddalena, Jennifer J. Roberts, Andrea Hamilton, Can Portland cement be replaced by low-carbon alternative materials? A study on the thermal properties and carbon emissions of innovative cements, Journal of Cleaner Production, Volume 186, 933-942, 2018. 
30. R. Dones, T. Heck, S. Hirschberg, GREENHOUSE GAS EMISSIONS FROM ENERGY SYSTEMS: COMPARISON AND OVERVIEW, https://www.osti.gov/etdeweb/servlets/purl/20547252.

31. Tukker, A., A. de Koning, R. Wood, T. Hawkins, S. Lutter, J. Acosta, J.M. Rueda Cantuche, M. Bouwmeester, J. Oosterhaven, T. Drosdowski, J. Kuenen (2013) EXIOPOL - Development and illustrative analyses of a detailed global $\mathrm{mr}$ ee sut/iot. Economic Systems Research, 25(1)50-70. doi: 10.1080/09535314.2012.761952

32. Wood, R., K. Stadler, T. Bulavskaya, S. Lutter, S. Giljum, A. de Koning, J. Kuenen, H. Schütz, J. Acosta-Fernández, A. Usubiaga, M. Simas, O. Ivanova, J. Weinzettel, J.H. Schmidt, S. Merciai, A. Tukker (2015) Global sustainability accounting-developing EXIOBASE for multi-regional footprint analysis. Sustainability, 7(1)138-163. doi: 10.3390/su7010138

33. Stadler K, R. Wood, T. Bulavskaya, C.J. Sodersten, M. Simas, S. Schmidt, A. Usubiaga, J. Acosta-Fernandez, J. Kuenen, M. Bruckner, S. Giljum, S. Lutter, S. Merciai, J.H. Schmidt, M.C. Theurl, C. Plutzar, T. Kastner, M. Eisenmenger, K. Erb, A. de Koning, A. Tukker (2018) EXIOBASE 3: Developing a Time Series of Detailed Environmentally Extended Multi-Regional Input-Output Tables, Journal of Industrial Ecology 22(3)502-515. doi: 10.1111/jiec.12715

34. Merciai, S. and J. Schmidt (2018) Methodology for the Construction of Global MultiRegional Hybrid Supply and Use Tables for the EXIOBASE v3 Database. Journal of Industrial Ecology, 22(3)516-531. doi:10.1111/jiec.12713

35. Hoekstra, R. and J. C. J. M. van den Bergh. 2006. Constructing physical input-output tables for environmental modeling and accounting: Framework and illustrations. Ecological Economics 59(3): 375-393.

36. SEEA (System of Environmental-Economic Accounting). 2012. System of Environmental-Economic Accounting: A central framework . European Commission, International Monetary Funds, Food and Agriculture Organization of the United Nation, Organisation for Economic Co-operation and Development, United Nations, and World Bank. White cover publication. https://unstats.un.org/unsd/envaccounting/seeaRev/SEEA_CF_Final_en.pdf. Accessed 29 September 2016.

37. WNA, Comparison of Lifecycle Greenhouse Gas Emissions of Various Electricity Generation Sources, http://www.worldnuclear.org/uploadedFiles/org/WNA/Publications/Working_Group_Reports/compariso n_of_lifecycle.pdf

38. Zhao, Z., Chen, T., Ghoniem, A.F., Rotary Bed Reactor for Chemical-Looping Combustion with Carbon Capture. Part 1: Reactor Design and Model Development, Energy Fuels, 27, 327-343. 2013

39. Hong, J., TECHNO-ECONOMIC ANALYSIS OF PRESSURIZED OXYFUEL COMBUSTION POWER CYCLE FOR CO2 CAPTURE, Master degree thesis, MIT, 2009.

40. Schjølset, S., The MSR: Impact on market balance and price, https://ec.europa.eu/clima/sites/clima/files/docs/0094/thomson_reuters_point_carbon_e n.pdf.

41. Fernandes, D.; Wang, S.; Xu, Q.; Buss, R.; Chen, D. Process and Carbon Footprint Analyses of the Allam Cycle Power Plant Integrated with an Air Separation Unit. Clean Technol. 1, 325-340. 2019 
42. Zampilli, M., Bidini, G., Laranci, P., D'Amico, M., Bartocci, P., Fantozzi, F., Biomass microturbine based EFGT and IPRP cycles: Environmental impact analysis and comparison, Proceedings of the ASME Turbo Expo, 3. 2017.

43. The Parliamentary Office of Science and Technology, Carbon Footprint of Electricity Generation, Post note update 2011.

44. Smoucha, E.A., Fitzpatrick, K., Buckingham, S., Knox, O.G.G., Life Cycle Analysis of the Embodied Carbon Emissions from 14 Wind Turbines with Rated Powers between $50 \mathrm{~kW}$ and $3.4 \mathrm{~kW}$, J Fundam Renewable Energy Appl, 6:4, 2016. 